\title{
A Study on the Dynamic Relationship Between Financial Development and Investment: Evidence from Sub-Saharan Africa
}

\author{
*Isaac Okyere Paintsil Zhao Xicang \\ Jiangsu University, School of Finance and Economics, 301 Xuefu Road, Zhenjiang. China PRC.
}

\begin{abstract}
The relationship between financial development and investment has become the central focus for empirical studies since the emergence of endogenous growth models. Bank-based measures and Financial markets-based measures have often been used as proxies for financial development in many studies. However, results based on these proxies have often yielded different interpretations since the concept of financial development is broad and a multidimensional process. The Financial development index of the International Monetary Fund (IMF) presents a more comprehensive measure for financial development, and it is also useful for investigating financial development and other economic outcomes. Also, investment is a versatile concept since it takes on many forms and sources. We adopt the panel VAR estimation techniques to examine the endogenous relationship between financial development and investment using the Financial development index, general government investment, private investment, and foreign direct investment (FDI) as dependent variables. The study reveals that private investment has a positive endogenous relationship with financial development. Moreover, the causal relationship between financial development and private investment is bilateral. Also, financial development has a positive influence on FDI. Furthermore, the study suggests that financial development has a strongly exogenous relationship with General government investment.
\end{abstract}

Keywords: Financial development index; Private investment; General government investment; Foreign direct investment; Panel VAR.

DOI: $10.7176 / \mathrm{JESD} / 10-14-09$

Publication date:July $31^{\text {st }} 2020$

\section{Introduction.}

The impact of financial development on economic growth is well entrenched in economic literature (see Goldsmith, (1969); Beck et al., (2000); Demetriades and Hussein, (1996); King (1993); Levine (1997); Levine and Zervos (1998); Demirgüç-Kunt and Levine (2004); Rousseau and Wachtel (2011)). Proponents of Endogenous growth also emphasize the importance of investment in the finance-growth nexus (Levine, 1997). Levine and Renelt (1992) suggest that an increase in the volume of investment in an economy intensifies the rate of economic growth. Thus, from the endogenous growth point of view, financial development leads to increased savings, which raises the level of capital accumulation for investment, and also leads to productivity (Demetriades and Hussein (1996); Levine (1997)).

A typical situation which mirrors the endogenous growth explanation is the recent gains in the economic growth of some sub-Saharan African countries where in the past financial development was lagging as a result of macroeconomic and political instability which plunged many countries the subregion into economic woes and widespread poverty. Some countries in the sub-Saharan Africa region underwent various forms of fiscal and financial reforms which aimed at boosting the investment. In recent year concrete evidence with respect to GDP seems to suggest that those policy interventions made an impact. According to an IMF report, the sub-Saharan African region is now becoming the fastest growing after Asia (IMF, 2016).

Empirical studies on financial development and investment are a central focus for many researchers and endogenous growth proponents. Majority of these studies makes use of bank-based variables or financial marketbased variables or both in many instances as proxies for financial development. However, the results have often yielded different interpretations due to the broad and multidimensional nature of financial development. Sackyi et al., (2016) underscore this opinion and echo that the impact of financial development on investment is susceptible to the indicators used for financial development since the notion of financial development is broad, and multidimensional.

Sahay et al. (2015) and Svirydzenka (2016) develop the Financial Development index that summarize how developed financial institutions and financial markets are according to their depth, access, and efficiency. According to Svirydzenka (2016), the Financial Development index presents a more comprehensive measure of financial development, and it is also useful for investigating financial development and other economic outcomes. However, no attempt has yet been made to use the Financial Development index to explore the dynamic relationship between financial development and investment in sub-Saharan Africa. This paper attempts to fill this gap.

This study adopts a country level panel data and the panel VAR method of estimation that based on the generalized method of moments (GMM) to empirically identify some main issues on financial development and 
investment in sub-Saharan Africa and make some recommendations. The application of panel VAR analysis by the GMM allows us to check for endogenous interactions between financial development and investment. The GMM also allows us to take care of small samples, endogeneity problems, and omitted variables. In addition to the stated objective, this study contributes to the growing literature on financial development and investment in two ways. The contribution of this study is two-fold:

1. We focus on sub-Saharan Africa, where major financial innovation and FinTech business activities are taking place. Thus, this study echoes the "finance-investment" interaction in sub-Saharan African countries and also provides a sub-Saharan African perspective on the subject.

2. Also, investment itself is a versatile concept, in that, it takes on different forms and sources; consequently, we adopt three different forms of investment, namely; Private investment, General government investment, and Foreign direct investment (FDI) for the analysis.

The rest of the paper is organized as follows. A brief review of some empirical literature is provided. Next, the data used in the study, followed by an outline of the methodology and model in the empirical study, are presented. Then the findings and discussions are provided. The last section provides the conclusion for the study.

\section{Brief literature review}

We discuss empirical literature on financial development and investment in subsection 2.1 and also review relevant empirical studies on financial development and FDI in subsection 2.2.

\subsection{Financial development and investment}

Caporale et al., (2005) study the relationship between financial development and investment using financial market variables on Chile, Korea, Malaysia, and the Philippines for the period 1979 to 1998. They conduct the Toda and Yamamoto causality test to determine the direction of causality within the variables. Their conclusion suggests that stock market development Granger-causes investment productivity in all four countries. Similarly, Carp (2012) use data on Romania for the period 1995 to 2010. He adopts vector autoregressive models (VAR) and Granger causality approach to observe the causal direction between financial development and investment. The variables used in the study include; the annual percentage growth of GDP at market prices, local currency market capitalization, turnover ratio, stocks traded, and total investment as a percentage of GDP. The outcome indicates that stock market capitalization Granger-causes investment.

Rousseau and Vuthipadadorn (2005) conduct a study on financial development and investment in ten Asian countries for the period 1950 to 2000. They adopt vector autoregressive models (VAR) and vector error correction (VECM) econometric techniques for the analysis. They use bank development variables as proxy for financial development. The study reveals that financial development leads to investment growth in seven countries, namely; India, Japan, Korea, Malaysia, Pakistan, Sri Lanka, and Thailand. Further, their findings show a bi-directional relationship between Financial Development and Investment for the Philippines and Singapore but no causal relationship between the variables for Indonesia. Hamdi et al. (2013) also study the nexus between Financial development and investment in Tunisia by conducting Multivariate Granger causality and vector error correction model (VECM). Their findings show that financial development Granger-cause Investment. Likewise, Asongu (2014) study the finance and investment dynamics of sixteen African countries using the vector error correction model (VECM) and several banking development indicators in his study. The finding shows that financial development Granger-cause investment.

Chaudhry et al. (2012), use the Engle-Granger and ECM approach to assesses the effectiveness of financial development in promoting investment in Pakistan over the period 1972-2006. The study attempts to capture the multidimensional aspects of financial development by including both banking development measures and financial market measures in the model equation. The findings show that broad money, private sector credit, and stock market capitalization are essential drivers of investment in the economy. Similarly, Muyambiri (2016) adopt a trivariate ARDL based causality to investigate the relationship between financial development and Investment in Mauritius. Their findings indicate that both banking development measures and financial market measures cause Investment. Muyambiri and Odhiambo (2017) investigate how financial development and Investment interact in South Africa using a trivariate causality model and ARDL bounds testing. The study indicates a bi-directional relationship between financial development and Investment.

\section{Financial development and FDI}

Studies on FDI and its impact on economic development have often produced interesting results. On the one hand, some studies provide evidence that FDI has a negative impact on an economy (Aitken and Harrison (1999); Gerschewski (2013)). For instance, Gerschewski (2013) argued that the productivity of domestic firms decreases when FDI increases. On the other hand, other studies stress that the FDI is important (Mello (1997); Todo (2003); Basu and Guariglia (2007)). The argument in favour of FDI often cite technological spillovers, sector competition, human capital formation, among others, as crucial evidence of the impact of FDI to host countries.

Some studies also attempt to explain the relationship between financial development and FDI. Anyanwu 
(2011) explains that financial development has a negative impact on FDI inflow in Africa. Abzari et al. (2011) examine the causality between financial development and FDI inflow between 1976-2005 in eight developing countries utilizing Vector Autoregressive (VAR) model and conclude that there is unidirectional causality from FDI to financial development. Nasser and Gomez (2009) study FDI inflow, banking, and capital market development, including 15 Latin American nations between the period of 1978 and 2003 using panel regression. They observe a positive relationship among FDI inflows, banking sector, and capital market development. Bayar (2014) also study the determinants of FDI inflows in seven EU transition economies from 1997 to 2011 . He concludes that financial development positively affected FDI inflows.

Similarly, Sahin and Ege (2015) observed the causal relationship between FDI inflows and financial development in four countries from 1996-2012. They observed a unilateral causality from FDI inflows to financial development in Bulgaria and Greece, and bilateral causality in Turkey using bootstrap causality tests. Gebrehiwot et al. (2016) examined the relationship between financial development and FDI using data on eight African countries between 1991-2013 using Granger causality tests and panel regression and found a bilateral causality between financial development and FDI.

\section{Materials and methods}

In this section, we present the materials and methods used in the analysis. The analysis needed a detailed countrylevel panel dataset on Financial development index, Private investment, and General government investment from the IMF database. Dataset on FDI inflow is also obtained from the World Bank data. The variables for the analysis and the summary statistics are described in section 3.1.

\subsection{Data}

The Financial Development index is developed for the IMF. Essentially, the index ranks the financial performance of an economy by measuring the growth of financial institutions and financial markets in terms of their depth, access, and efficiency. Data on Financial Development index, from now on, financial development is obtained from the IMF database.

Concerning investment, the most basic measure of domestic investment is the gross fixed capital formation, which according to the OECD glossary of statistical terms, is measured by the total value of the gross fixed capital formation, changes in inventories, and acquisitions excluding disposals of valuables for a unit or sector. In this study, Private investment and General government investment denoting gross fixed capital formation in billions of constant 2011 international dollars for the private sector and the public sector respectively are used. Data on Private investment and General government investment is also obtained from the IMF database. Furthermore, the study also examines the dynamic relationship between Financial development and FDI. Data on FDI inflow is obtained from the World Bank data.

The variables used in the study and their summary statistics are shown in Table 1. The values given in Table 1 are all the logarithm transformation from their original values.

Table 1:Descriptive statistics

\begin{tabular}{|c|c|c|c|c|c|c|c|}
\hline Variable & & Source & Obs & Mean & Std. Dev. & Min & $\operatorname{Max}$ \\
\hline $\begin{array}{l}\text { Financial development } \\
\text { index }\end{array}$ & $F D$ & IMF database & 496 & -2.30151 & .5517824 & -6.44722 & -.9509925 \\
\hline $\begin{array}{l}\text { General government } \\
\text { investment }\end{array}$ & $G G I$ & IMF database & 496 & -.274749 & 1.561531 & -4.39980 & 3.645517 \\
\hline Private investment & $P I$ & IMF database & 496 & .4347733 & 1.753468 & -5.03636 & 4.684652 \\
\hline Foreign direct investment & $F D I$ & $\begin{array}{c}\text { World Bank } \\
\text { data }\end{array}$ & 479 & 18.88799 & 2.136078 & 10.36072 & 22.90268 \\
\hline
\end{tabular}

Table 1. presents the values for the number of observations, the mean, standard deviation, minimum value, and maximum value. Missing values for FDI means that the variable enters the analysis with 479 observations.

\subsection{Panel unit root test.}

The first step in time series and panel data analysis is to conduct the unit root test. The test allows us to determine whether the variables involved in the study are nonstationary or stationary. The presence of unit root in the panel data would indicate that statistical inferences using the data are problematic and not reliable. In other words, the presence of unit root indicates that we cannot reliably undertake hypothesis tests about the model. In that case, there is a need for differencing of the nonstationary variables to induce stationarity. We inspect for the existence unit root in the data using the Cross-sectionally Augmented Dickey-Fuller (CADF) of Pesaran (2007) unit root test technique. The Pesaran (2007) test is based on augmenting the ADF regression with lagged cross-sectional mean and its first difference, which captures the cross-sectional dependence that arises through a single-factor model. According to Table 2, every series is stationary at levels and at the first difference. 
Table 2: CADF Unit root test results

\begin{tabular}{cccc}
\hline Variable & \multicolumn{2}{c}{ Stat. test } & P-value \\
& t-bar & $Z(t$-bar $)$ & \\
\cline { 2 - 3 }$\triangle F D$ & -2.380 & -3.550 & 0.000 \\
$\triangle F D$ & -3.404 & -8.601 & 0.000 \\
$G G I$ & -2.199 & -2.559 & 0.005 \\
$\triangle G G I$ & -2.583 & -4.406 & 0.000 \\
$P I$ & -2.402 & -3.670 & 0.000 \\
$\triangle P I$ & -2.786 & -5.445 & 0.000 \\
$F D I$ & & -2.295 & 0.011 \\
$\triangle F D I$ & & -4.259 & 0.000 \\
\hline
\end{tabular}

The statistic test is the Cross-sectionally Augmented Dickey-Fuller (CADF) of Pesaran (2007). The test has the null hypothesis of the presence of a unit root. For unbalanced panels, only standardized Z(t-bar) statistic is calculated.

\subsection{Panel cointegration test.}

A cointegration test is a common technique in a statistical and econometric study to determine the existence of a long run relationship. The panel cointegration test proposed by Pedroni (1999), which is classified among the first generation cointegration tests, is often used in econometric analysis. The test produces seven cointegration test statistics, of which four are based on within dimensions, and the three others are based on between dimensions. The null hypothesis for all the dimensions is no cointegration within the variables. From Table 3, we notice that three out of the seven test statistics reject the null hypothesis of no cointegration at a $1 \%$ significance level. Thus, we can conclude that there is cointegration between some of the variables in the model.

\subsection{Cross-sectional dependence test.}

A test of cross-sectional dependence is an important diagnostic test to conduct in panel data analysis. The crosssectional dependence test allows us to determine how situations in individual countries in our samples are related or interconnected. The outcome of this test would help us to make generalizations about the similarities in financial development and investment situations in Africa. To determine cross-sectional dependence, we applied the simple test of Pesaran (2004) and calculated the cross-section dependence (CD) statistic. The test is based on the average pair-wise correlation coefficients of the ordinary-least-squares (OLS) residuals attained from standard Augmented Dickey-Fuller (ADF) regressions for each individual. The null hypothesis is that there is cross-sectional independence, and the variable is asymptotically distributed as a two-tailed standard normal distribution. The results given in Table 4 indicate that the null hypothesis is rejected at the $1 \%$ level of significance for every series. This finding shows that low income Sub-Saharan African countries are cross-sectionally correlated, which indicate the presence of similar financial systems and investment environment.

\subsection{Lag selection}

The lag selection for the panel VAR is calculated through the pvarsoc command in Stata using the first four lags of the dependent variables as instruments. The correct length selection is essential for panel VAR estimation. Choosing lags that are too short fails to capture the essential dynamics which lead to omitted variable bias and choosing too many lags creates a loss of degrees of freedom that results in over-parameterization. Based on the lag selection estimates in Table 5, we select the first order panel VAR, which has the highest J statistic and the smallest MBIC, MAIC, and MQIC for our analysis.

Table 3: Panel cointegration test results.

\begin{tabular}{lcc}
\hline & Statistic & Weighted Statistic \\
\hline & Common AR coefficients (within-dimension) \\
Panel v-Statistic & -1.208910 & -1.237718 \\
Panel rho-Statistic & 0.378117 & 0.826092 \\
Panel PP-Statistic & $-3.543786^{* * *}$ & $-4.413947 * * *$ \\
Panel ADF-Statistic & -1.244993 & $-5.084056^{* * *}$ \\
& Individual AR coefficient (between-dimension) \\
Group rho-Statistic & 2.928927 & \\
Group PP-Statistic & $-5.763532^{* * *}$ & \\
Group ADF-Statistic & $-5.058050^{* * *}$ & \\
\hline
\end{tabular}

Note $^{* * *}$ and ${ }^{* *}$, and $*$ represents the rejection of the null hypothesis at $1 \%$ and $5 \%$ and $10 \%$ level of significance respectively. 
Table 4: Panel cross-sectional dependence test

\begin{tabular}{ccc}
\hline Variable & CD-test & p-value \\
\hline$F D$ & 29.16 & 0.000 \\
\hline$G G I$ & 41.82 & 0.000 \\
\hline$P I$ & 55.53 & 0.000 \\
\hline$F D I$ & 38.28 & 0.000 \\
\hline
\end{tabular}

Table 5: Lag selection results.

\begin{tabular}{lcccccc}
\hline Lags & \multicolumn{5}{c}{ Interaction between $F D$ GGI PI FDI. } \\
\hline & CD & J & J p-value & MBIC & MAIC & MQIC \\
$\mathbf{1}$ & .9999414 & 44.587 & 0.61351 & -229.355 & -51.4134 & -122.618 \\
$\mathbf{2}$ & .9999397 & 20.454 & 0.94293 & -162.174 & -43.5460 & -91.0157 \\
$\mathbf{3}$ & .9998441 & 11.617 & 0.76996 & -79.6977 & -20.3839 & -44.1187 \\
\hline
\end{tabular}

3.6. The panel VAR model.

The panel VAR approach is preferred for this study since it can capture the heterogeneities in cross-section unit interdependencies. The panel VAR allows us to feature the lagged effects of financial development on investment and check if there is feedback from investment to financial development. Secondly, the forecast error variance decomposition (FEVD) allows us to understand how much variation in a variable is explained by other variables. Thirdly, the Impulse Response Function (IRFs) from the panel VAR allows us to highlight the dynamic response of investment to idiosyncratic shock on financial development and vice versa. Finally, the panel Granger causality analysis based on the panel VAR estimates allows us to ascertain the direction of the causal relationship between financial development and investment. A stationary panel VAR model is of the form;

$X_{i t}=\gamma(L) X_{i t}+u_{i t}+e_{i t} \quad, i=1, \ldots, N, t=1, \ldots, T$

where $X_{i t}$ is a vector of dependent variables, $\gamma(L)$ is a matrix polynomial in the lag operator $u_{i t}$ is a vector of country-specific fixed effects, and $e_{i t}$ is the vector of idiosyncratic errors.

The panel VAR technique allows for individual heterogeneity in all the variables by introducing fixed effects to ensure that the underlying structure is equal for all panels. However, for dynamic panels, fixed effects are correlated with the regressors due to the lags of the dependent variable. This is resolved by applying the forwardmean differencing procedure such that the means of all future observations available for each panel and time is eliminated in order to maintain the orthogonality between transformed variables and lagged independent variables (Love and Zicchino, 2006). After fixed effects are removed, the generalized method of moments (GMM), which uses lagged regressors as instruments, is used for the estimation.

The main objective of this study is to determine the relationship between financial development and investment using Financial Development index, General government investment, private investment, and FDI as dependent variables. We specify a first order $4 \times 4$ panel VAR model as follows;

$F D_{i, t}=\alpha_{10}+\sum_{j=1}^{m} \alpha_{1,1} F D_{i, t-j}+\sum_{j=1}^{m} \alpha_{2,1} G G I_{i, t-j}+\sum_{j=1}^{m} \alpha_{3,1} P I_{i, t-j}+\sum_{j=1}^{m} \alpha_{4,1} F D I_{i, t-j}+\mu_{1 i, t}+u_{1 i, t}$

$G G I_{i, t}=\alpha_{20}+\sum_{j=1}^{m} \alpha_{2,1} F D_{i, t-j}+\sum_{j=1}^{m} \alpha_{2,2} G G I_{i, t-j}+\sum_{j=1}^{m} \alpha_{2,3} P I_{i, t-j}+\sum_{j=1}^{m} \alpha_{2,4} F D I_{i, t-j}+\mu_{2 i, t}+u_{2 i, t}$

$P I_{i, t}=\alpha_{30}+\sum_{j=1}^{m} \alpha_{3,1} F D_{i, t-j}+\sum_{j=1}^{m} \alpha_{3,2} G G I_{i, t-j}+\sum_{j=1}^{m} \alpha_{3,3} P I_{i, t-j}+\sum_{j=1}^{m} \alpha_{3,4} F D I_{i, t-j}+\mu_{3 i, t}+u_{3 i, t}$

(4)

$F D I_{i, t}=\alpha_{40}+\sum_{j=1}^{m} \alpha_{4,1} F D_{i, t-j}+\sum_{j=1}^{m} \alpha_{4,2} G G I_{i, t-j}+\sum_{j=1}^{m} \alpha_{4,3} P I_{i, t-j}+\sum_{j=1}^{m} \alpha_{4,4} F D I_{i, t-j}+\mu_{4 i, t}+u_{4 i, t}$

(5)

here, $\mu_{1 i, t} \mu_{2 i, t} \mu_{3 i, t}$, and $\mu_{4 i, t}$, are individual fixed effects, $u_{1 i, t}, u_{2 i, t}, u_{3 i, t}$, and $u_{4 i, t}$ are white noise errors, $i=$ $1, \ldots, N$ refers to the $i t h$ country, $t=1, \ldots, T$ refers to the time period, $m$ refers to the lagged number, $F D_{i, t}$ denotes financial development, $G G I_{i, t}$ denotes general government investment, $P I_{i, t}$ denotes private investment, and $F D I_{i, t}$ FDI inflows.

We also check for the stability of our estimated panel VAR model. The stability condition of panel VAR is critical to ensure the panel VAR is invertible and has a finite-order vector moving-average representation. It also ensures that the estimates can be reliable for generation Impulse Response Functions (IRFs) and Forecast Error Variance Decomposition (FEVD). Lütkepohl (2005) explain that a VAR model is stable if all moduli of the companion matrix are strictly $<1$. We use the post-estimation command pvarstable to check the stability by calculating the modulus of each eigenvalue in our models. Also, we compute the FEVD based on the causal ordering and the IRFs. The IRFs intervals are calculated by 200 Monte Carlo simulations based on the estimated model.

The Granger causality test is also widely used in an econometric analysis to examine the causality between 
certain economic variables (Granger, 1969). In this study, the panel VAR Granger causality Wald test is used to determine the direction of causality among the variables. Within this framework, we can determine whether the lagged coefficient of the financial development helps to predict general government investment, private investment, and FDI. The Granger causality test is based on the hypothesis below;

$H_{0}$ : Excluded variable does not Granger-cause Equation variable.

$H_{1}$ : Excluded variable Granger-cause Equation variable.

\section{Results of Empirical Analysis and Discussion.}

The main results for the panel VAR estimation, Forecast Error Variance Decomposition (FEVD), Impulse Response Functions (IRFs), and Granger causality test are discussed in this section.

\subsection{Panel VAR estimation coefficients.}

\begin{tabular}{cllll}
\multicolumn{5}{c}{ Table 6: Panel VAR estimation results. } \\
\hline & $\boldsymbol{F D}$ & $\boldsymbol{G G I}$ & $\boldsymbol{P I}$ & $\boldsymbol{F D I}$ \\
\hline $\boldsymbol{F} \boldsymbol{D}_{\boldsymbol{t}-\mathbf{1}}$ & 0.978 & -0.041 & -0.455 & 1.249 \\
& $(0.000)$ & $(0.882)$ & $(0.028)$ & $(0.088)$ \\
\hline $\boldsymbol{G} \boldsymbol{G I}_{\boldsymbol{t}-\mathbf{1}}$ & -0.038 & 0.606 & -0.100 & -0.673 \\
& $(0.196)$ & $(0.000)$ & $(0.225)$ & $(0.012)$ \\
\hline $\boldsymbol{P} \boldsymbol{I}_{\boldsymbol{t}-\mathbf{1}}$ & 0.107 & .195 & .842 & 1.019 \\
& $(0.004)$ & $(0.073)$ & $(0.000)$ & $(0.000)$ \\
\hline $\boldsymbol{F} \boldsymbol{D I}_{\boldsymbol{t}-\mathbf{1}}$ & -0.036 & 0.0917 & 0.176 & 0.558 \\
& $(0.367)$ & $(0.466)$ & $(0.057)$ & $(0.073)$ \\
\hline
\end{tabular}

Note: The four-variable VAR model is estimated by GMM; Country-specific and fixed effects are removed prior to estimation. $p$-values are in brackets.

Source: Author's estimation.

Table 6 presents the panel VAR estimation coefficients for financial development, general government investment, private investment, and FDI. It can be observed that past values of financial development are strongly associated with a $0.978 \%$ increase of the financial development in the short run, at a $1 \%$ significance level on average ceteris paribus. Thus, financial development has a strong influence on its future values. The results also suggest that a percentage increase in private investment is associated with $0.107 \%$ increase in financial development in the short run, at a $1 \%$ significance level on average ceteris paribus. Hence, the influence of private investment on financial development positive but inelastic.

The results also suggest that past realization of general government investment is associated with a $0.606 \%$ increase in general government investment in the short run, at a $1 \%$ significant level on average ceteris paribus. The coefficient estimates also suggest that a percentage increase in private investment contributes to $0.195 \%$ increase in general government investment in the short run, at a 10\% significant level on average ceteris paribus. Hence, the effect of private investment on general government investment is also positive but inelastic.

We observe that the past fulfillment of private investment is firmly is associated with a $0.842 \%$ increase in private investment volume in the short run, at a $1 \%$ significance on average ceteris paribus. Also, a percentage increase in financial development leads to a $0.455 \%$ decrease in private investment in the short run, at a $5 \%$ significant level on average ceteris paribus. Thus, financial development has a negative effect on private investment. Besides, a percentage increase in FDI contributes to a $0.176 \%$ increase in private investment in the short run, at a $10 \%$ significance level on an average ceteris paribus. Hence, the influence of FDI on Private investment is positive.

The past values of FDI are also associated with a $0.558 \%$ increase in the FDI inflow in the short run, at a $10 \%$ significant level on average ceteris paribus. A percentage increase in general government investment is associated with a $0.673 \%$ decrease in FDI in the short run, at a $5 \%$ significance level on an average ceteris paribus. Thus, general government investment and FDI demonstrate a negative relationship. Also, a percentage increase in financial development is associated with a $1.249 \%$ increase in FDI in the short run, at a $10 \%$ significance level on average ceteris paribus. Therefore, financial development has a perfectly elastic and a positive influence on FDI. Furthermore, a percentage increase in private investment is associated with a $1.019 \%$ increase in FDI in the short run, at a $1 \%$ significant level on average ceteris paribus. Hence, the impact of private investment on FDI is also positive and elastic. 


\subsection{Panel VAR stability test results.}

Table 7: Panel VAR stability test results.

\begin{tabular}{ccc|c|c|}
\hline \multicolumn{3}{c|}{ Panel VAR model } & Modulus \\
\hline Real & Imaginary & 0.913354 \\
0.9115946 & -0.0566647 & 0.913354 \\
0.9115946 & 0.0566647 & 0.6953198 \\
0.6953198 & 0 & 0.4654465 \\
0.4654465 & 0 & 0 & \\
\hline
\end{tabular}

Table 7 presents the results for the panel VAR stability test results. It can be observed that the estimated panel VAR model satisfy the stability condition as all the eigenvalues lay within the unit circle. Thus, we can proceed to examine the endogenous relationships by their FEVD outcome.

\subsection{Forecast Error Variance Decomposition (FEVD) results.}

Table 8:FEVD results

\begin{tabular}{|c|c|c|c|c|c|}
\hline & & $F D$ & $G G I$ & $P I$ & $F D I$ \\
\hline \multirow[t]{11}{*}{$F D$} & 0 & 0 & 0 & 0 & 0 \\
\hline & 1 & 1 & 0 & 0 & 0 \\
\hline & 2 & 0.9535986 & 0.0017879 & 0.020263 & 0.0243506 \\
\hline & 3 & 0.9129431 & 0.0025439 & 0.0455344 & 0.0389786 \\
\hline & 4 & 0.8819468 & 0.0027726 & 0.0724422 & 0.0428383 \\
\hline & 5 & 0.8549675 & 0.0029084 & 0.1011269 & 0.0409973 \\
\hline & 6 & 0.8277418 & 0.0031436 & 0.1315733 & 0.0375412 \\
\hline & 7 & 0.7982059 & 0.0036022 & 0.1632048 & 0.0349871 \\
\hline & 8 & 0.7659832 & 0.0043923 & 0.1950581 & 0.0345664 \\
\hline & 9 & 0.7317486 & 0.0055915 & 0.2260592 & 0.0366007 \\
\hline & 10 & 0.6966646 & 0.0072245 & 0.2552592 & 0.0408517 \\
\hline \multirow[t]{11}{*}{$G G I$} & 0 & 0 & 0 & 0 & 0 \\
\hline & 1 & 0.0000153 & 0.9999847 & 0 & 0 \\
\hline & 2 & 0.0008871 & 0.9282418 & 0.0360554 & 0.0348156 \\
\hline & 3 & 0.0030031 & 0.787367 & 0.1193429 & 0.090287 \\
\hline & 4 & 0.0051741 & 0.6292225 & 0.222361 & 0.1432424 \\
\hline & 5 & 0.0064886 & 0.4944097 & 0.3162812 & 0.1828204 \\
\hline & 6 & 0.0068557 & 0.3947833 & 0.3892188 & 0.2091422 \\
\hline & 7 & 0.0065845 & 0.3256838 & 0.4416682 & 0.2260636 \\
\hline & 8 & 0.0060037 & 0.2786849 & 0.4781857 & 0.2371258 \\
\hline & 9 & 0.0053408 & 0.246646 & 0.5033268 & 0.2446864 \\
\hline & 10 & 0.0047257 & 0.2245457 & 0.5205809 & 0.2501476 \\
\hline \multirow[t]{11}{*}{$P I$} & 0 & 0 & 0 & 0 & 0 \\
\hline & 1 & 0.000391 & 0.0512422 & 0.9483668 & 0 \\
\hline & 2 & 0.0045245 & 0.0350367 & 0.8624937 & 0.0979451 \\
\hline & 3 & 0.006101 & 0.0215894 & 0.7872372 & 0.1850724 \\
\hline & 4 & 0.0062348 & 0.0170714 & 0.7384742 & 0.2382196 \\
\hline & 5 & 0.0059426 & 0.018831 & 0.7074465 & 0.26778 \\
\hline & 6 & 0.0056249 & 0.0237986 & 0.6867374 & 0.2838391 \\
\hline & 7 & 0.0054034 & 0.0299847 & 0.6720343 & 0.2925777 \\
\hline & 8 & 0.0053015 & 0.0363122 & 0.6609737 & 0.2974125 \\
\hline & 9 & 0.0053125 & 0.0422651 & 0.6522487 & 0.3001737 \\
\hline & 10 & 0.0054205 & 0.0476339 & 0.6451132 & 0.3018324 \\
\hline \multirow[t]{8}{*}{$F D I$} & 0 & 0 & 0 & 0 & 0 \\
\hline & 1 & 0.0604305 & 0.0131309 & 0.037503 & 0.8889356 \\
\hline & 2 & 0.1040617 & 0.014199 & 0.1623857 & 0.7193537 \\
\hline & 3 & 0.1214636 & 0.0249687 & 0.2730787 & 0.580489 \\
\hline & 4 & 0.1227174 & 0.0349376 & 0.3533761 & 0.4889689 \\
\hline & 5 & 0.1168708 & 0.0425363 & 0.4100905 & 0.4305024 \\
\hline & 6 & 0.108548 & 0.4905525 & 0.45051 & 0.3926696 \\
\hline & 7 & 0.0998796 & 0.0527711 & 0.4796275 & 0.3677218 \\
\hline
\end{tabular}




\begin{tabular}{ccccc}
\hline & $\boldsymbol{F D}$ & $\boldsymbol{G} \boldsymbol{G}$ & $\boldsymbol{P I}$ & $\boldsymbol{F D I}$ \\
\hline 8 & 0.0917931 & 0.0564682 & 0.500746 & 0.3509926 \\
9 & 0.0846407 & 0.0596325 & 0.5161066 & 0.3396201 \\
10 & 0.0785003 & 0.0624218 & 0.5272737 & 0.3318042 \\
\hline
\end{tabular}

Table 8 presents the FEVD results for the dependent variables based on the panel VAR estimates. The FEVD for financial development reaffirms that the it is strongly endogenous to its future values. Also, $25 \%$ of the total variance in financial development is explained by a shock to private investment. Thus, the FEVD reveals that private investment is weakly endogenous to financial development. Furthermore, FDI explains $4 \%$ of the total variance in financial development, indicating a strong exogenous relationship between the two variables. Similarly, general government investment's contribution to financial development is not significantly different from zero, indicating a strong exogenous relationship.

The FEVD for general government investment shows that it is strongly endogenous to its future values in the short run but exhibits a weak influence on itself in the long run. We also observe that $52 \%$ of the total variance in general government investment occurs as a result of a shock to private investment. Thus, private investment exhibits a strong influence on future values of general government investment. Similarly, $25 \%$ of the total variance in general government investment occurs as a result of a shock to FDI. Hence FDI also exhibits a strong influence on General government investment. The results also suggest that the proportion of variance in general government investment explained by financial development is not significantly different from zero. Thus, financial development exhibits a strong exogenous relationship with general government investment.

The private investment FEVD shows that private investment has a strong endogenous effect on its future realizations. The results also reveal that $30 \%$ of the total variance in private investment is explained by FDI. Hence, FDI has a robust endogenous influence on private investment. We can also observe that general government investment and financial development exhibit a strong exogenous effect on private investment, indicating that they have a weak influence on the future realizations of private investment.

FDI exhibits a strong endogenous effect on its future values in the short run but shows a weak influence in the long run. Private investment exhibits a strong influence on FDI as it explains $52 \%$ of the total variance in FDI. We also observe that Financial development and General government explain $7 \%$ and $6 \%$ of the total variance in FDI, respectively, indicating that they have a robust exogenous relationship with FDI.

\subsection{Impulse response functions.}

Figure 1 presents the IRFs results, the accumulated response to a shock to financial development are summarized as follows:

1. A negative shock to financial development causes private investment to decrease slightly.

2. A negative shock to financial development causes general government investment to increase slightly in the short run.

3. A negative shock to financial development causes a slight increase in FDI but gradually decrease in the long run.

The response of financial development to impulse from general government investment, private investment, and FDI are summarized as follows:

1. A negative shock to General government investment has an insignificant effect on financial development.

2. A shock to Private investment causes financial development to increase.

3. A shock to FDI inflow causes financial development to increase slightly in the short run but decreases in the long run.

The IRFs are advantageous, in that, we can observe the type of shock to a variable and also observe the accumulated responses from the variable. For example, we can observe that the effect of financial development on the other dependent variables is due to a negative shock in the IRFs. Furthermore, the associated confidence interval is helpful in determining the level of certainty for each response. Thus, the widening confidence interval for each the response indicates that the long run effects shown in the IRFs are less specific. 
Figure 1 Impulse response function.
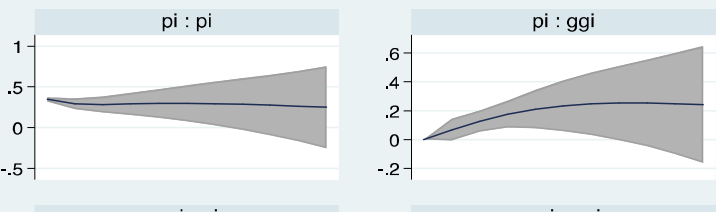

ggi : ggi

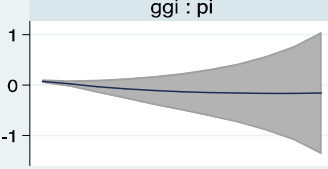

fdi : pi

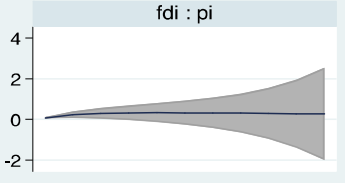

fd : pi
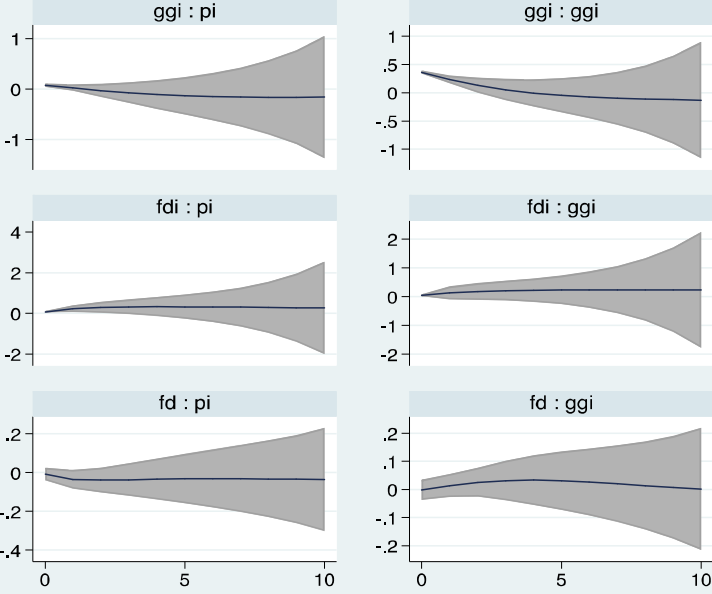

fdi : ggi

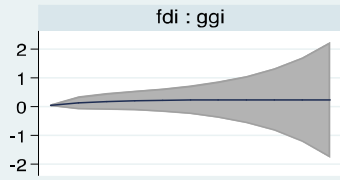

fd : ggi

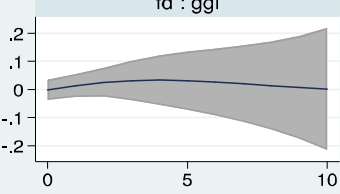

step

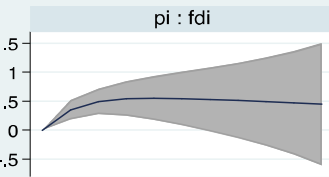

ggi : fdi

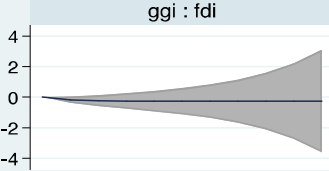

fdi : fdi

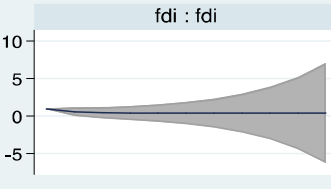

fd : fdi

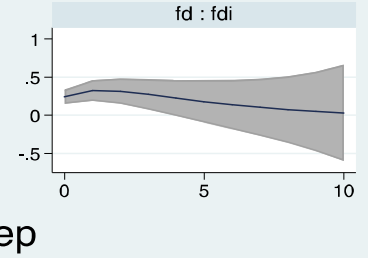

Orthogonalized IRF

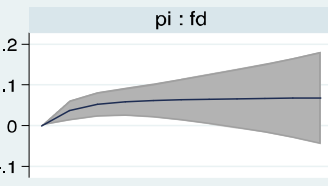

ggi : fd

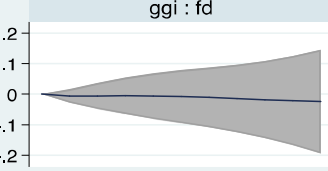

fdi : fd

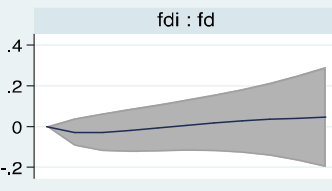

$f d: f d$

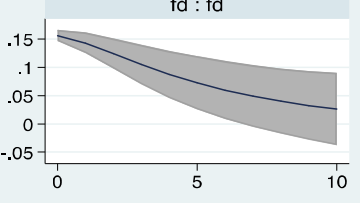

$95 \% \mathrm{Cl}$

impulse : response

\subsection{Granger causality test results.}

The Granger causality test is a useful panel data technique to determine whether one variable is useful for predicting another variable. Thus, results from the Granger causality test provides robustness to the panel VAR estimates. We discuss the causality between financial development and each form of investment in this subsection. 4.5.1. Pair-wise comparison of financial development and general government investment.

According to Table 9, the $P$-value for the causality from general government investment to financial development is not significant at a $10 \%$ significance level, so we accept the null hypothesis that general government investment does not Granger cause financial development. Likewise, the $P$-value for the causality from financial development to general government investment is also not significant at a $10 \%$ significance level, so we accept the null hypothesis that financial development does not Granger cause general government investment. Hence, there is no causality between the two variables.

\subsubsection{Pair-wise comparison of Financial development and Private investment.}

According to Table 9, the $P$-value for the causality from private investment to financial development is significant at a $1 \%$ significance level. Hence, we reject the null hypothesis and accept the alternative hypothesis that private investment Granger causes financial development index. Also, the $P$-value for the causality from financial development to private investment is significant at a 5\% significance level so, we can reject the null hypothesis and accept the alternative hypothesis that financial development Granger causes Private investment. Hence, there is bilateral causality between the two variables.

4.5.3. Pair-wise comparison of Financial development and FDI.

According to Table 9, the $P$-value for the causality from FDI to financial development is not significant at a $10 \%$ significance level, so we accept the null hypothesis that FDI does not Granger cause financial development. The $P$-value for the causality from the financial development to FDI is significant at a $10 \%$ significance level, so we can reject the null hypothesis and accept the alternative hypothesis that financial development Granger causes FDI. Hence, there is a unilateral causality from financial development index to FDI.

4.5.4. Pair-wise comparison of financial development, general government investment, private investment, and FDI.

According to Table 9, the $P$-value for the joint causality from general government investment, private investment, and FDI to financial development is significant at $1 \%$ significance level, so we reject the null hypothesis and accept the alternative hypothesis that General government investment, private investment, and FDI jointly Granger cause financial development. 
Table 9: Granger causality test results.

\begin{tabular}{|c|c|c|c|c|}
\hline & & Chi2 & $d f$ & Prob $>$ chi2 \\
\hline \multirow{4}{*}{$F D$} & $G G I$ & 1.675 & 1 & 0.196 \\
\hline & $P I$ & 8.420 & 1 & $0.004 * * *$ \\
\hline & FDI & 0.815 & 1 & 0.367 \\
\hline & $A L L$ & 13.975 & 3 & $0.003 * * *$ \\
\hline \multirow[t]{4}{*}{$G G I$} & $F D$ & 0.022 & 1 & 0.882 \\
\hline & $F D I$ & 0.532 & 1 & 0.466 \\
\hline & $P I$ & 3.206 & 1 & $0.073 *$ \\
\hline & $A L L$ & 21.556 & 3 & $0.000 * * *$ \\
\hline \multirow[t]{4}{*}{$P I$} & $F D$ & 4.834 & 1 & $0.028 * *$ \\
\hline & $F D I$ & 3.620 & 1 & $0.057 *$ \\
\hline & $G G I$ & 1.474 & 1 & 0.225 \\
\hline & $A L L$ & 5.007 & 3 & 0.171 \\
\hline \multirow[t]{4}{*}{$F D I$} & $F D$ & 2.903 & 1 & $0.088^{*}$ \\
\hline & $G G I$ & 6.288 & 1 & $0.012 * *$ \\
\hline & $P I$ & 17.329 & 1 & $0.000 * * *$ \\
\hline & $A L L$ & 25.357 & 3 & $0.000 * * *$ \\
\hline
\end{tabular}

Note: ${ }^{* * *},{ }^{* *}$, and $^{*}$ represents the rejection of the null hypothesis at $1 \%$ and $5 \%$ and $10 \%$ level of significance respectively.

\subsection{Discussions.}

This study examines the dynamic relationship between financial development and investment in sub-Saharan African countries using the Financial development index as the measure of how development the financial institutions and financial markets are in sub-Saharan Africa. The major findings relating to our objective are summarized in Table 10.

\begin{tabular}{|c|c|c|c|c|c|c|}
\hline & FD to GII & GII to FD & FD to PI & PI to FD & FD to FDI & FDI to FD \\
\hline $\begin{array}{l}\text { Level of } \\
\text { endogeneity }\end{array}$ & $\begin{array}{l}\text { Strongly } \\
\text { exogenous }\end{array}$ & $\begin{array}{l}\text { Strongly } \\
\text { exogenous }\end{array}$ & $\begin{array}{l}\text { Strongly } \\
\text { exogenous }\end{array}$ & $\begin{array}{l}\text { Weakly } \\
\text { endogenous }\end{array}$ & $\begin{array}{l}\text { Strongly } \\
\text { exogenous }\end{array}$ & $\begin{array}{l}\text { Strongly } \\
\text { exogenous }\end{array}$ \\
\hline $\begin{array}{l}\text { Direction of } \\
\text { endogeneity }\end{array}$ & None & None & Negative & Positive & Positive & None \\
\hline Causality & None & None & \multicolumn{2}{|c|}{ Bilateral } & unilateral & None \\
\hline
\end{tabular}

The findings from this study provide evidence that there is no endogenous relationship between financial development and general government investment within sub-Saharan African countries. This finding could reflect how local governments generates funding for infrastructural development in sub-Saharan Africa since many countries within the subregion often depend on loans from external sources and international donor countries. Consequently, local financial institutions often do not play a significant role in financing public infrastructural development. Furthermore, it is also possible that local governments are less involved in the development of their financial sectors by way of investment through partnerships, funding, and the provision of incentives that promote the financial development in their economies.

The study also reveals that financial development has a negative influence on private investment due to an adverse shock. As already mentioned in the introduction section of this study, financial development in subSaharan African has regressed for decades, consequently, financial development has had detrimental effects on private investment in the subregion leading to economic stagnation and widespread poverty. The recent development in the financial sector due to the adoption of FinTech is helping to turn this negative tide and also promote investment. Jack and Suri (2011) explain that timely money transfers, through financial technology such as mobile money, enable households to smooth their consumption and make more effective investment decisions in Sub-Saharan Africa.

Furthermore, the results suggest that private investment has a positive influence on financial development. Thus, Private investment provides financial institutions and financial markets the avenues to expand their profits through loans and other financial instruments, which also helps them to embrace innovation and improve their services. Also, evidence from Granger causality suggests that the causal relationship between financial development and Private investment is bilateral. This finding concurs with the opinion of some proponents of the endogenous finance-growth models (e.g., Greenwood and Smith, 1997), because an increase in investment volume would lead to a rise in the demand for external financing, which also causes financial intermediaries to persuade households to increase their savings.

The study also reveals that financial development has a positive effect on FDI. The finding concurs with 
Desbordes and Wei (2017), which suggests that FDI source and destination countries' financial development jointly stimulate FDI by directly increasing access to external finance and indirectly supporting the overall economic activity. The role of FDI is still a bone of contention among many researchers. However, the success story of China with regards to the influence of FDI on local economies is a good signal for many policymakers in sub-Saharan Africa. Thus, promoting the private sector is a useful strategy to attract FDI inflow into sub-Saharan Africa.

Table 11: Summary of findings on GGI, PI, FDI.

\begin{tabular}{|c|c|c|c|c|c|c|}
\hline & PI to GGI & GGI to PI & PI to FDI & FDI to PI & GGI to FDI & $\begin{array}{ll}\text { FDI } & \text { to } \\
\text { GGI }\end{array}$ \\
\hline $\begin{array}{l}\text { Level of } \\
\text { endogeneity }\end{array}$ & $\begin{array}{l}\text { Strongly } \\
\text { endogenous }\end{array}$ & $\begin{array}{l}\text { Strongly } \\
\text { exogenous }\end{array}$ & $\begin{array}{l}\text { Strongly } \\
\text { endogenous }\end{array}$ & $\begin{array}{l}\text { Strongly } \\
\text { endogenous }\end{array}$ & $\begin{array}{l}\text { Strongly } \\
\text { exogenous }\end{array}$ & $\begin{array}{l}\text { Weakly } \\
\text { endogenous }\end{array}$ \\
\hline $\begin{array}{l}\text { Direction of } \\
\text { endogeneity }\end{array}$ & Positive & Negative & Positive & Positive & Negative & Positive \\
\hline $\begin{array}{l}\text { Direction of } \\
\text { causality }\end{array}$ & Unilateral & None & \multicolumn{2}{|c|}{ Bilateral } & None & Unilateral \\
\hline
\end{tabular}

Findings relating to the dynamic interactions among the different forms of investment are summarized in

Table 11. According to Table 11, private investment is strongly endogenous to general government investment. Similarly, the Granger causality test results also indicate that private investment granger causes general government investment. Furthermore, we observe from Table 11 that FDI also contributes positively to general government investment. These findings show the impact of the private sector and multinational companies on government revenues which enables governments to undertake developmental projects in their countries. Furthermore, we observe that FDI contributes positively to general government investment.

Policymakers in sub-Saharan African countries often try to ensure that their economies are attractive and fertile for multinational companies due to the anticipated positive effects FDI has on local industries and the gross domestic product (GDP). This study also reveals the importance of the private sector for FDI inflow. Thus, it is possible that an increase in Private investment indicates a high return on investment in an economy, which attracts FDI and motivate governments to improve infrastructure in order to promote the investment environment. Consequently, we observe a bilateral relationship between private investment and FDI in sub-Saharan Africa.

\section{Conclusion}

This study examined the dynamic relationship between financial development and investment in 31sub-Saharan African countries for the period of 2000-2015 via the panel VAR estimation techniques. The study adopted the Financial development index of the IMF and examined its endogenous relationship with private investment, general government investment, and FDI.

The study reveals that is no causal relationship between financial development and general government investment in sub-Saharan Africa. We also found that there is a bilateral causal relationship between financial development and Private investment. However, we noticed that even though financial development is exogenous to private investment, it contributes negatively to private investment in sub-Saharan Africa. The study further shows that financial development has a positive influence on FDI. Also, FDI and private investment have a bilateral endogenous relationship.

Our findings have some policy implications for countries in sub-Saharan Africa. We recommend that policymakers should focus on promoting private sector development due to its ability to drive financial development and attract FDI inflow, as revealed in this study. The influence of the private sector on government revenue can also not be overlooked since an increase in revenue for the government would also boost public infrastructural development.

\section{References}

Abzari, M., Zarei, F. and Esfahani, S. (2011), “Analyzing The Link between Financial Development and Foreign Direct Investment among D-8 Group of Countries”, International Journal of Economics and Finance, Vol. 3, available at: https://doi.org/10.5539/ijef.v3n6p148.

Aitken, B.J. and Harrison, A.E. (1999), "Do Domestic Firms Benefit from Direct Foreign Investment? Evidence from Venezuela”, American Economic Review, Vol. 89 No. 3, pp. 605-618.

Anyanwu, J. (2011), Working Paper 135 - International Remittances and Income Inequality in Africa, No. 325, African Development Bank, available at: https://ideas.repec.org/p/adb/adbwps/325.html (accessed 26 January 2020).

Asongu, S. (2014), "Linkages between Investment Flows and Financial Development: Causality Evidence from Selected African Countries", SSRN Electronic Journal, Vol. 5, pp. 269-299.

Basu, P. and Guariglia, A. (2007), "Foreign Direct Investment, inequality, and growth", Journal of 
Macroeconomics, Vol. 29 No. 4, pp. 824-839.

Bayar, Y. (2014), "DETERMINANTS OF FOREIGN DIRECT INVESTMENT INFLOWS IN THE TRANSITION ECONOMIES OF EUROPEAN UNION”, No. 4, p. 6.

Beck, T.H.L., Levine, R. and Loayza, N. (2000), "Finance and the sources of growth", Journal of Financial Economics, Vol. 58 No. 1-2, pp. 261-300.

Caporale, G.M., Howells, P. and Soliman, A.M. (2005), "Endogenous Growth Models and Stock Market Development: Evidence from Four Countries", Review of Development Economics, Vol. 9 No. 2, pp. 166176.

Carp, L. (2012), “Can Stock Market Development Boost Economic Growth? Empirical Evidence from Emerging Markets in Central and Eastern Europe", Procedia Economics and Finance, Vol. 3, pp. 438-444.

Chaudhry, I., Malik, A. and Frooq, F. (2012), "Financial Liberalization and Macroeconomic Performance: Empirical Evidence from Pakistan", Finance and Management Sciences, Vol. 4.

Demetriades, P.O. and Hussein, K.A. (1996), "Does financial development cause economic growth? Time-series evidence from 16 countries", Journal of Development Economics, Vol. 51 No. 2, pp. 387-411.

Demirgüç-Kunt, A. and Levine, R. (2004), Financial Structure and Economic Growth: A Cross-Country Comparison of Banks, Markets, and Development, MIT Press.

Desbordes, R. and Wei, S.-J. (2017), "The effects of financial development on foreign direct investment", Journal of Development Economics, Vol. 127, pp. 153-168.

Gebrehiwot, A., Esfahani, N. and Sayim, M. (2016), "The Relationship between FDI and Financial Market Development: The Case of the Sub-Saharan African Region”, International Journal of Regional Development, Vol. 3 No. 1, p. 64.

Gerschewski, S. (2013), "Do Local Firms Benefit from Foreign Direct Investment? An Analysis of Spillover Effects in Developing Countries", Asian Social Science, Vol. 9, pp. 67-76.

Goldsmith, R.W. (1969), Financial Structure and Development, Yale University Press, New Haven.

Granger, C.W.J. (1969), "Investigating Causal Relations by Econometric Models and Cross-spectral Methods", Econometrica, Vol. 37 No. 3, pp. 424-438.

Greenwood, J. and Smith, B.D. (1997), "Financial markets in development, and the development of financial markets", Journal of Economic Dynamics and Control, Vol. 21 No. 1, pp. 145-181.

Hamdi, H., Hakimi, A. and Sbia, R. (2013), "Multivariate Granger Causality between Financial Development, Investment and Economic Growth: Evidence from Tunisia", Journal of Quantitative Economics: Journal of the Indian Econometric Society, Vol. 11.

INTERNATIONAL MONETARY FUND. (2016), Financial Development in Sub-Saharan Africa., INTL MONETARY FUND, Place of publication not identified.

Jack, W. and Suri, T. (2011), Mobile Money: The Economics of M-PESA, No. w16721, National Bureau of Economic Research, Cambridge, MA, p. w16721.

King, R.G. *Levine. (1993), Finance and Growth: Schumpeter Might Be Right, No. 1083, The World Bank, available at: https://ideas.repec.org/p/wbk/wbrwps/1083.html (accessed 26 January 2020).

Levine, R. (1997), "Financial Development and Economic Growth: Views and Agenda", Journal of Economic Literature, Vol. 35 No. 2, pp. 688-726.

Levine, R. and Renelt, D. (1992), "A Sensitivity Analysis of Cross-Country Growth Regressions", The American Economic Review, Vol. 82 No. 4, pp. 942-963.

Levine, R. and Zervos, S. (1998), "Stock Markets, Banks, and Economic Growth", The American Economic Review, Vol. 88 No. 3, pp. 537-558.

Love, I. and Zicchino, L. (2006), "Financial development and dynamic investment behavior: Evidence from panel VAR", The Quarterly Review of Economics and Finance, Vol. 46 No. 2, pp. 190-210.

Lütkepohl, H. (2005), New Introduction to Multiple Time Series Analysis, Springer-Verlag, Berlin Heidelberg, available at:https://doi.org/10.1007/978-3-540-27752-1.

Mello, L.R. de. (1997), "Foreign direct investment in developing countries and growth: A selective survey", The Journal of Development Studies, Vol. 34 No. 1, pp. 1-34.

Muyambiri, B. (2016), "THE SEQUENCING OF FINANCIAL REFORMS AND BANK-BASED FINANCIAL DEVELOPMENT IN MAURITIUS”, Journal of Accounting and Management, Vol. 6 No. 1, pp. 89-114.

Muyambiri, B. and Odhiambo, N.M. (2017), The Causal Relationship between Financial Development and Investment in Botswana, No. 22607, University of South Africa, Department of Economics, available at: https://ideas.repec.org/p/uza/wpaper/22607.html (accessed 26 January 2020).

Nasser, O.M. and Gomez, X.G. (2009), "Do well-functioning financial systems affect the FDI flows to latin america?", Vol. 1, pp. 60-75.

Pagano, M. (1993), "Financial markets and growth: An overview”, European Economic Review, Vol. 37 No. 2 , pp. 613-622.

Pedroni, P. (1999), "Critical Values for Cointegration Tests in Heterogeneous Panels with Multiple Regressors", 
Oxford Bulletin of Economics and Statistics, Vol. 61 No. S1, pp. 653-670.

Pesaran, M.H. (2004), General Diagnostic Tests for Cross Section Dependence in Panels, SSRN Scholarly Paper No. ID 572504, Social Science Research Network, Rochester, NY, available at: https://papers.ssrn.com/abstract=572504 (accessed 26 January 2020).

Pesaran, M.H. (2007), “A simple panel unit root test in the presence of cross-section dependence”, Journal of Applied Econometrics, Vol. 22 No. 2, pp. 265-312.

Rousseau, P.L. and Vuthipadadorn, D. (2005), "Finance, investment, and growth: Time series evidence from 10 Asian economies", Journal of Macroeconomics, Vol. 27 No. 1, pp. 87-106.

Rousseau, P.L. and Wachtel, P. (2011), "What Is Happening to the Impact of Financial Deepening on Economic Growth?”, Economic Inquiry, Vol. 49 No. 1, pp. 276-288.

Sahay, R., RSahay@imf.org, Cihak, M., MCihak@imf.org, N’Diaye, P., PN’Diaye@imf.org, Barajas, A., et al. (2015), "Financial Inclusion: Can it Meet Multiple Macroeconomic Goals?", Staff Discussion Notes, Vol. 15 No. 17, p. 1.

Sahin, S. and Ege, I. (2015), "Financial Development and FDI in Greece and Neighbouring Countries: A Panel Data Analysis", Procedia Economics and Finance, Vol. 24, pp. 583-588.

Sakyi, D., Kofi Boachie, M. and Immurana, M. (2016), "Does Financial Development Drive Private Investment in Ghana?", Economies, Vol. 4 No. 4, p. 27.

Svirydzenka, K. and KSvirydzenka@imf.org. (2016), “Introducing a New Broad-based Index of Financial Development", IMF Working Papers, Vol. 16 No. 05, p. 1.

Todo, Y. (2003), "Empirically consistent scale effects: An endogenous growth model with technology transfer to developing countries”, Journal of Macroeconomics, Vol. 25 No. 1, pp. 25-46. 